\title{
ACHIEVING SUSTAINABILITY HUMAN RESOURCES DEVELOPMENT
}

\author{
Dr.C K Gomathy, K.Harshawardhan,Unnam Pavithra,K.Vishnu Vardhan. \\ Sri Chandrasekharendra Saraswathi Viswa Mahavidyalaya , Kanchipuram
}

\begin{abstract}
Sustainability is often associated with the natural environment, but it is actually multidimensional architecture that includes profit objectives, the Planet, and the people. In any organization, Human Resource Management (HRM) work should focus on achieving sustainability policies related to people, a section often overlooked in sustainability negotiations .Continuous Human Resource Management - a collection of personnel policies, procedures, and policies focuses on assisting financial, social, and environmental goals by managing people-the difference between organizational success and organizational efficiency. Only by involvement Sustainable HRM the organization can achieve its highest potential by increasing its capacity for this "part of the people" to achieve the goals and strategy of its business, present and future .Continuous Human Resource Management enables an organization to achieve its goals, while simultaneously empowering its employees to maximize their potential and achieve their goals in life. We present a review of sustainability and HR literature, and then we want to integrate these two ideas with a focus on opportunities for sustainable use in HR development. We use staff training facilities and performance appraisal as examples of creative thinking and innovation that needs to be brought to HRM for real improvement the human part of the Triple Bottom Line.
\end{abstract}

\section{Keywords:}

Human Sustainability, Employee Sustainability, Sustainable Human Resource Management, Sustainable Development, Human Resource Development.

\section{Introduction}

Human Resource Management (HRM) may not be automatically linked to sustainability, however there is a strong and distinct connection between these two topics. Lots of very wide published and recommended ideas for sustainability such as "The Triple Bottom Line", The "Stakeholder Theory", and the "Shared Value", highlight the importance of people and employees as an important need to create a sustainable organization. Negotiations on harassment, fair wages, paid leave, and income inequality among others directly related to Human Resources (HR) and sustainable human processes everywhere globe. Although international companies face a different approach expectations about their HRM in the countries where they operate, the global political situation brings much needed focus to the human part of the Triple Bottom Line - People, Planet, and Benefits. In less regulated workplaces, major employee and community concerns are related to provision to protect basic employment, low wages, and benefits. In contrast, regulated workplaces that provide multiple services in developed countries exist an opportunity to discuss best practices in personnel management conflicts (HRM) and Social Security Responsibility (CSR) Responsibility. In these regulated workplaces, rules in particular it provides more protection for workers, and labour professionals 
may be able to "Focus on ensuring that the company lives up to the spirit and the letter of the law, and moves on apart from the rules in terms of diversity issues, balance of working life, training and employment, pension provision, anti-harassment, etc. Focus on these situations where HR work can consider better ways to move forward sustainability, this paper seeks to define Sustainable HRM, state its objectives, and evaluate activities and staff development goals as an opportunity to participate stable business processes. Although, the name Sustainable HRM is relatively new, there is no well-established definition in the text. In his analysis of Sustainable HRM research, Kramar (2014) outlines a few different approaches to sustainable human resources management, including mechanisms seeking organizational survival by ensuring a sustainable staff provision; HR activities that support environmental performance (again called Green HRM); and HR processes that take into account the social and environmental consequences internally as well themselves, and not just as the cause or mediator of financial performance. While acknowledging the differences in these research streams, Kramar (2014) provides this explanation Ongoing HRM, Continuous HRM can be defined as a planned or emerging HR pattern strategies and processes aimed at making it financially, socially and environmental goals while simultaneously reproducing the HR base in the long run. The goal of Sustainable HRM should be to treat people as human beings, not as a means to an end financial policy. Stable Human Resource Management enables an organization to achieve its goals, at the same time empowering its staff to develop their professional and personal skills and reach their goals in life. Ongoing development in HRM can make a difference in organizations to achieve their mission statement and the organizations striving to achieve their vision for the future. First we present a review of sustainability and personnel literature, and then try to integrate this two concepts with a focus on opportunities for sustainable use in human resource development. We use staff training and performance analysis areas as examples of art new ideas and innovations that need to be brought to HRM for real human development part of the Triple Bottom Line.

\section{Sustainability}

One of the most quoted descriptions of sustainable development comes from United Report of the National's Brundtland Commission 1987 - Our Common Future, From One Earth to One World, "Sustainable development is a development that meets the current needs outside to reduce the ability of future generations to meet their needs. "This broad definition of sustainability should be reduced to a minimum in order to be applied to understanding the issue of sustainability in different areas. Adam Werbach, CEO of Saatchi and the former president of the Sierra Club, did an excellent job of using common sense in working language that is easily understood by business professionals: For my purposes, a stable business means a business that can thrive over time term. Stability is greater than PR stunt or green product line, even greater rather than from the heart but from time to time in an ongoing effort to save the planet. Considered and fully utilized, sustainability carries out a basic cost-saving strategy, a an advanced strategy for accessing a new customer base, and a talent strategy for acquiring, retaining, and developing a skilled workforce. (Werbach, 2009, page 9) Webach's view of sustainable business is actually the use of John Elkington (1994) The Triple Bottom Line Statistics Framework, which encourages companies to focus on social media, environmental and financial consequences - commonly referred to as 3Ps: Profits, People and Planet. This the model challenges the corporate focus on profit - the "bottom line" or the latter in the Profit and Loss account-- and states that firms need to improve metrics to measure results by their decisions about people and nature. One of the most important issues for this The framework is that all three "bottom lines" are equally important and very sustainable processes occur in human interaction, planetary, and profit. 


\section{Achieving Sustainability}

In a recent study, respondents were asked about interactions between employees management function and sustainability. Organizations show investment in stability leads to positive results, which include "1) the improvement of employee morals, 2) a more efficient business processes, 3) a strong public image, 4) increasing employee loyalty, and 5) increasing productivity recognition ". These results are supported by Appropriate Global Reporting Initiative Indicators in Labour Relations. Traditionally, by calculating the return on investment (ROI) and other HR metrics for sustainability. organizations can create a business case for integrating sustainability processes organizational philosophy and practice. The challenge for Sustainable HRM is that well-being environmental effects, not just financial performance, should be supported by HR. By integrating sustainability into the culture and strategies of the organization, the organization participants are more likely to accept and accept these programs. In addition, these organizations see an increase in levels of job satisfaction, ethical development, and staff development to become future leaders of the organization (SHRM et al., 2011). With the proposed steps of sustainability to is a success, organizations need the support of senior management to lead change along the way employees are monitored and managed .The involvement of the HR department in the organization is the key to incorporating these philosophies into the whole company.

\section{A. Sustainability through Employee Needs}

One theory companies can use to incorporate sustainable human resource development Management is the full implementation of Maslow's (1943) Hierarchy of Needs, one of the first. official ideas about mobilizing people. Maslow identified five performance requirements in total people: physical needs, safety and security, love and presence, self-confidence, and self-reliance. This theory is presented as a pyramid with five key mental entities requirements in the sequence of the continuation of the phase, in which the requirements of the lower level must be met one to see the needs of the highest level. The important thing to note is that once a person is moving at the top of the list, one can step back after a major health event that is as bad as natural disaster, divorce, job loss, etc. A lot of things go into the assessment of what salaries should be given however, to Maslow Hierarchy, a company needs to pay a person enough to not worry about making a living. Illegal research shows that remuneration is not the most important factor in employment satisfaction but one of the main reasons for job dissatisfaction results in companies low-wage workers.

In fact Glassdoor.com, one of the leading online job search engines, has been released a study that reports a significant impact of higher income levels on employee satisfaction culture as well prices, job opportunities, senior leadership, working life balance, compensation and benefits, and business vision (Nunez, 2015). By paying employees the same wage / salary and providing certain types of similar benefits health care, health insurance, retirement, etc. companies can, at the very least, allow the work to fulfill some of their basic needs so they can contribute to the company, but this employee will do it it may be an employee who has stopped working. By fulfilling only the basic needs of employees, the company there are likely to be employees who "just come in" and "shut out," and who come in literally working only to collect income.

If a company can create an inspiring culture communication, friendship, and cooperation between employees and not one where they are ongoing competition or employees live in fear, the company can move employees the need to develop self-confidence. We argue that part of the role of HR manager is to promote employee priorities interests when participants clash. Although this is contrary to the agency-theory view that $\mathrm{i}$ The corporation should be managed to increase shareholder wealth, blends well with growth a body of 
literature in management and business law representing a focused business theory company life (Bower \& Paine, 2017). Although this seems to speak idyllic or even a utopian company, this is a current practice in countries like Switzerland as described Zaugg, Blum, and Thom also reported by Kramar (2014). It may be unusual in some countries, but there are examples such as Sir Richard Branson, founder of Virgin Group Ltd. It went so far as to say that employees are first, customers second, and shareholders follow. Sustainable HRM's change the focus on maximizing profits you can make using your own staff, to increase the capacity of the human part of the organization; from short-term to long-term performance to performance. This is where Human Resource Development (HRD) work can also help individual organizations to succeed. Sadly, in 1983 the United Nations Commission on Bruntland identified it "Human resource development is an important need and not just to build technology knowledge and skills, but also the creation of new standards to help individuals and nations cope rapidly changing social, environmental, and developmental realities". Significantly, the commission identifies HRD as an important sector for ensuring sustainability development at different rates. So, we think it is worth focusing on HR development work, as an important area for promoting sustainability in HRM. This is HRD's place "It includes opportunities such as staff training, staff development, efficiency management and development, training, mentoring, sequencing planning, key staff identification, learning support, and organizational development $"$

Focusing on HRD serves to initiate dialogue about the integration of sustainability and HR. Where rental or compensation policies may be changed by executive fiat, consolidation Sustainability in HRD is a long-term goal because it requires changes in organizational culture and in the minds of the people who are being developed in the organization. Although there are many aspects of HRD where managers can improve the sustainability of part of the people of their organizations, we will focus on training, career planning, and performance management.

\section{B. Sustainability through Training and Development}

One of the best places to promote HR stakeholder vision is to invest in training and personal behaviour staff development. Organizations often find themselves trained in new solutions hiring, rehabilitating employees to transform industry knowledge or strategic business processes, and improve them personnel skills or skills for professional / personal development, or where employees are encouraged and in need of adjustment in relation to quality work commitments. Human capital development is one of the areas where labour can help sustainability change (SHRM, et al. 2011). Studies have proven the benefits of investing in employees through on-the-job training and personal and professional experience development, staff research shows that job development opportunities are an area where companies need to work harder, in particular because these same employees place job development as the second most important factor attractive works.

A recent American survey ,The Psychological Association (APA) has shown that although most workers think they have a right skills to do well in their current job, about half of the U.S. employees surveyed are concerned a change in the nature of their trade. For these people, those who see that there is a shortage management support for their job development centre to leave the company within a year (APA) Centre for Organizational Excellence, 2017). Companies may be wary of making this investment, especially as employees live on average of 4.6 years in any given job (U.S. Bureau of Labor Statistics, 2014), and accordingly report "Multiple Generations @ Work", 91\% of Millennium life expectancy three years. Of all age groups, the 2015 survey found that $93 \%$ of them workers move forward in their careers by changing companies, rather than rising traditionally organizational ladder, which creates problems with profit margins, group power, and holes in the middle pipeline to senior management positions. 
A manager with an annual budget for training and development may be concerned allocate their training dollars by accurately identifying the employees they will be staying with organization. This investment in traditional training focuses on financial outcomes; therefore, trying to improve Return on investment (ROI) by predicting which employees will stay. Staff training as such that they stay and are based on the idea of treating people like any other service managed, work to be done more with the purchase of goods than social media or ethics anxiety. Here's what the model might look like after the management has identified the employees they trust will travel or stay with the organization:

Table-1: Training Investment Model Development Opportunities

\begin{tabular}{|c|c|c|}
\hline \multirow{2}{*}{ Development Opportunities } & \multicolumn{2}{|c|}{ Employee's Decision } \\
\hline & Stay & Leave \\
\hline Train & $\begin{array}{l}\text { Good Investment } \\
\text { Good Returns }\end{array}$ & $\begin{array}{l}\text { Bad Investment } \\
\text { No returns }\end{array}$ \\
\hline Do Not Train & $\begin{array}{l}\text { No Investment } \\
\text { No returns }\end{array}$ & $\begin{array}{l}\text { No investment } \\
\text { No returns }\end{array}$ \\
\hline
\end{tabular}

This investment training model clearly directs the manager to choose who to train with departmental Budget : people who are likely to stay, as they invest in potential employees leaving is considered a bad decision. Sadly, this model fails to consider the non-financial impact of training, and treats people like investment dollars. For example, Guest suggested that the organization performance should not be the only concern of HR professionals, as there are many others helpful personnel-related outcomes, such as satisfaction, community involvement, organizational climate, etc.

Under the Sustainable HRM policy, a manager must remember two principles: first, seek treat people as human beings; and second, it enables employees to develop their own skills. These two principles are not so good when an employee is leaving recently. Stable The Staff Training Model does not try to predict which employees will stay and leave, because it recognizes the importance of the long-term social outcomes of this training whether workers are leaving. This approach is in line with Guest's view of "HRM practices should be built to lead to HRM results for high staff dedication, high quality staff, and highly adaptable staff ". Importantly, companies should avoid the common mistake of not providing opportunities for applications new skills employees acquired after training. Additionally, the benefits of this type training can also be extended (Train-Stay cell in Table 2) if the company follows Internal promotion policy, with few advantages: it creates more employees the commitment and conduct of the citizenship organization , creates social networks and soft resources within the company, creates a sense of fairness, and ensures that those in charge of the company are aware of the business . 
Table-2: Sustainable Model of Employee Training

\begin{tabular}{|l|l|l|}
\hline \multirow{2}{*}{ Development Opportunities } & \multicolumn{2}{|c|}{ Employee's Decision } \\
\cline { 2 - 3 } $\begin{array}{l}\text { Train } \\
\text { (Invest) }\end{array}$ & $\begin{array}{l}|c| \\
\text { Successful planning for the } \\
\text { future of the firm. } \\
\text { Increases the likelihood of the } \\
\text { employee staying. }\end{array}$ & $\begin{array}{l}\text { Increased industry reputation as } \\
\text { people developer. } \\
\text { Recruiting top talent. }\end{array}$ \\
\hline $\begin{array}{l}\text { Do Not Train } \\
\text { (No investing) }\end{array}$ & $\begin{array}{l}\text { Undeveloped Talent that will } \\
\text { stagnate the firm. } \\
\text { Ineffective employees }\end{array}$ & $\begin{array}{l}\text { Could lose people with potential of } \\
\text { talent due to lack of development. } \\
\text { Difficulty recruiting. }\end{array}$ \\
\hline
\end{tabular}

Examples of the method presented in Table 2 are the many US-based companies committed to prioritizing staff training and education - even apparently non-existent sponsorship qualifications about a company business. Starbucks offers a full 4 year degree online scholarship in any field at Arizona State University for 25,000 employees, and benefits are available in any a job that works 20 hours or more. More educated workers will have more job opportunities in the markets however, a study from the US Bureau of Labour Statistics shows that these workers are they are more likely to stay because they like the benefits of training that is after training these staff they want more training, probably because employees have a long-term vision you have chosen for these programs.

\section{Sustainability through Performance Appraisal}

As we approach the idea of sustainability in HR, one of the ideas to be addressed is performance appraisal. According to the UN Global Compact, the largest field in the world a business sustainability campaign, with more than 8,000 companies and 4,000 non-business partners based in more than 160 countries, "the inclusion of sustainable performance management and compensation conditions are generally considered to reflect the true integration of organizational sustainability ". For many managers and employees, performance appraisal is one of the most misunderstood things parts of the human resource process.

The traditional performance test focuses on comparisons performance standards for a particular employee. From annual or second annual performance reviews to continuous performance management, managers are able to focus more in activities that "align all efforts with the "true north 'of your company" to direct policies, managers and human resource professionals are able to focus on improving work by training and guidance, as well as giving the employee the opportunity to do so understand how they contribute to the overall success of the organization. Implement goal alignment strategies and performance management, human resources departments can invest in the success and growth of employees, not just as assets organization but as individuals. By aligning employee and organizational policies with employees are able to see the real connection between their work and that of the company. This the visual link allows the employee to develop a sense of work value, which can lead to a a sense of purpose about their work.

As organizations continue to look for more Ways to keep their employees engaged, providing "essential work" represents a potential financial benefit that is particularly relevant to the generation of young talent who recognize the well-being and the environment. Another way to manage performance is through skills. Experts in businesses that are familiar with the concept of key skills from an organization or business vision; 
However this concept can be applied to the labour sector managers. According to the Society for Human Resource Management (SHRM), "Skills are a specific work ethic of employees in line with work performance, either it is measured and can be used efficiently in all many labour-related programs within the company to improve the overall performance of the organization "(Society for Human Resource Management, 2013).

The know-how has changed the way many companies deal with their HR process, especially selection and performance testing. Appropriate performance management approach focuses on development and evaluation of various abilities. By using this method, the company can not only focus on the work you have done, but in the skills needed to succeed at different levels of organization. This requires management to focus on the ethics and skills of employees, which can lead to management involvement they do not work as humans, not just some kind of asset. Such an approach can be rewarding for managers who like to see themselves as human developers, but can also be a source of sustainable competitive advantage.

\section{CONCLUSION}

In our view, the framework of Sustainability in Human Resources, needs to be guided by a single foundation The goal: treat people as people - not as ideas or intentions to achieve a particular goal, but as a conclusion themselves. This can be a problem in an area that refers to people as "property" and that, as an issue in fact, human expressions as resources. Although we do not examine the effects of these labels, we look at possible problems in this regard with regard to dismissals, dissatisfaction, and profit.

A sustainable environment requires more than just the fruit of energy and energy inefficiency to improve environmental performance. Although it is important to keep progress in environmental sustainability, it is also important to start a dialogue about half the population of the Triple Bottom Line, and especially in terms of managing staff in a more sustainable manner. We can see calls for this in European and US protests demanding better wages, better employee protection, and a better working life balance. Human Resources has an important role to play in promoting long-term sustainability and consideration of employees like some of the most important stakeholders.

We argue that Human Resource Development is an important area where HR professionals can do better apply a stakeholder perspective that places employees at the top of their list. Although these costs can be difficult to reconcile with a useful HR view, an investment in training should be seen as a prerequisite for being a self-employed employer.

In the field of human resource development, continuous analysis, staff coordination and the goals of the organization, as well as the information-based approach to obtaining feedback are some of the ways in which they do so companies can respond to the Global Compact of the United Nations to include people who are part of the company's Triple Bottom Line.

We hope that the integration of sustainability in human resource management provides the opportunity for companies to experience improved employee and organizational outcomes, as well as this Focus on people an area that has received less attention than part of its environment Commitment programs, but appropriate for growing commitments to be realized promises of organizational sustainability. 


\section{References}

[1.Dr.C K Gomathy, Article: A Study on the recent Advancements in Online Surveying , International Journal of Emerging technologies and Innovative Research ( JETIR ) Volume 5 | Issue 11 | ISSN : 23495162, P.No:327-331, Nov-2018

2.Dr.C.K.Gomathy,C K Hemalatha, Article: A Study On Employee Safety And Health Management International Research Journal Of Engineering And Technology (Irjet)- Volume: 08 Issue: 04 | Apr 2021

3. Dr.C K Gomathy, Article: A Study on the Effect of Digital Literacy and information Management, IAETSD Journal For Advanced Research In Applied Sciences, Volume 7 Issue 3, P.No-51-57, ISSN NO: 2279-543X,Mar/2018

4. Dr.C K Gomathy, Article: An Effective Innovation Technology In Enhancing Teaching And Learning Of Knowledge Using Ict Methods, International Journal Of Contemporary Research In Computer Science And Technology (Ijcrcst) E-Issn: 2395-5325 Volume3, Issue 4,P.No-10-13, April '2017

5.Dr.C K Gomathy, Article: Supply chain-Impact of importance and Technology in Software Release Management, International Journal of Scientific Research in Computer Science Engineering and Information Technology ( IJSRCSEIT ) Volume 3 | Issue 6 | ISSN : 2456-3307, P.No:1-4, July-2018

[6].Brundtland, G., Khalid, M., Agnelli, S., Al-Athel, S., Chidzero, B., Fadika, L., Hauff, V., Lang, I., Shijun, M., De Botero, M., Singh, M. \& Okita, S. (1987). Our common future ('Brundtland report'). United Nations World Commission on Environment and Development. Retrieved from http://www.un-documents.net/ocf-ov.htm

[7].Chalofsky, N. \& Krishna, V. (2009). Meaningfulness, commitment, and engagement:The intersection of a deeper level of intrinsic motivation. Advances in Developing Human Resources, 11(2), 189-203.

\section{AUTHOR'S PROFILE:}

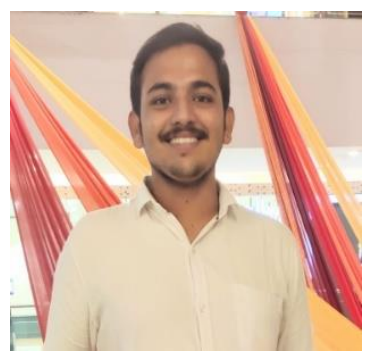

1. K Harsha Wardhan, student, B.E. Computer Science and Engineering, Sri Chandrasekharendra SaraswathiViswa Mahavidyalaya deemed to be university,Enathur,Kanchipuram,India. His area of interest is in Software Development and Human Resources Development. 


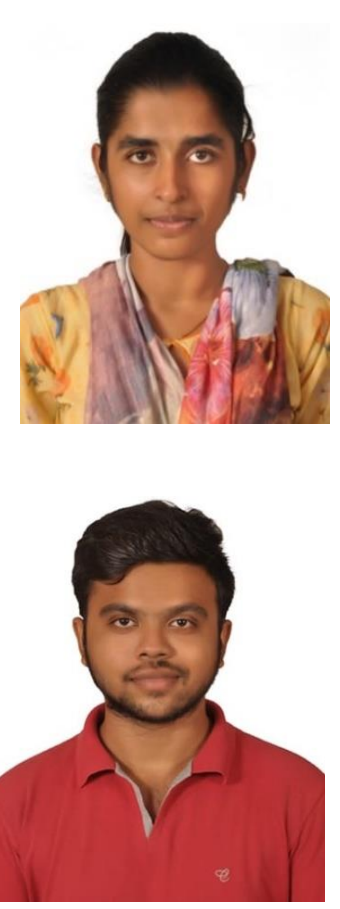

2. Unnam Pavithra, student, B.E. Computer Science and Engineering, Sri Chandrasekharendra SaraswathiViswa Mahavidyalaya deemed to be university,Enathur,Kanchipuram,India. Her area of interest is in Software Development and Human Resources Development.

3. K Vishnu Vardhan, B.E. Computer Science and Engineering, Sri Chandrasekharendra Saraswathi Viswa Mahavidyalaya deemed to be university,Enathur,Kanchipuram,India. His area of interest is in Software Development and Human Resources Development.

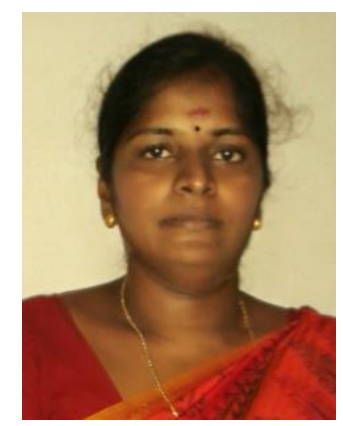

4. Dr.C.K.Gomathy is Assistant Professor in Computer Science and Engineering at Sri Chandrasekharendra SaraswathiViswa Mahavidyalaya deemed to be university,Enathur,Kanchipuram,India. Her area of interest is Software Engineering, Web Services,Human Resource and Knowledge Management and IOT. 